\title{
Popular music, Psychogeography, Place Identity and Tourism: The case of Sheffield
}

Dr Philip Long, Bournemouth University

\begin{abstract} 'soundscape' of the city.

Keywords: Music tourism, city identity, music scenes, Psychogeography

Dr Philip Long

Head of Tourism Academic Group

Bournemouth University

Talbot Campus

Poole, BH12 5BB

UK

plong@ bournemouth.ac.uk
\end{abstract}

Tourism and cultural agencies in some English provincial cities are promoting their popular music 'heritage' and, in some cases, contemporary musicians through the packaging of trails, sites, 'iconic' venues and festivals. This paper focuses on the case of Sheffield, a 'postindustrial' northern English city which is drawing on its associations with musicians past and present in seeking to attract tourists. The paper is based on interviews with, among others, recording artists, promoters, producers and venue managers, along with reflective observational and documentary data. Theoretical remarks are made on the representations of popular musicians through cultural tourism strategies, programmes and products and also on the ways in which musicians convey a 'psychogeographical' sense of place in the 


\section{Popular music, Psychogeography, Place Identity and Tourism: The case of Sheffield}

\section{Introduction: The sounds of the city}

Some 'world' cities such as Rome, Paris, New York, Rio de Janeiro and London feature in the lyrics of popular songs that are widely familiar. Senses of local and national 'character' are conveyed through the compositions and instrumentation that evoke images and emotions stereotypically associated with such cities and nations. Examples include the sound of accordions and the romantic compositions that feature Paris, Samba and Bossa Nova rhythms referring to Rio de Janeiro, and the jazz swing sounds of New York City. An aural, 'soundscape' of such cities thus exists in the popular imagination, conjured by recordings, broadcasts, films and television soundtracks. These stereotypical soundscapes may also be heard in the streets, hotels, bars and clubs that are frequented by tourists in these cities.

Other, provincial cities lay claims to being the (or a) 'birthplace' of genres such as New Orleans and jazz, Nashville and Country and Western, Chicago and the Blues, Memphis and Rock and Roll, with these connections expressed both in the sense of 'heritage', but also with artists emerging, recording and performing in these cities. Other places are distinguished as being birthplaces of famous individuals or groups of musicians such as Salzburg and Mozart, Bonn and Beethoven, Liverpool and the Beatles. As Johansson and Bell (2009: 9) succinctly put it, 'place is omnipresent in music and, reciprocally, music is clearly evident in place.' And, for Connell and Gibson (2004: 4), '...depictions and descriptions of places are recurring themes in musical commodities', to which might be added the point that contemporary recording artists themselves may willingly or otherwise become a part of such place representation processes.

Keeling (2011: 113) argues that "popular songs....reflect a particular geographic experience at a certain point in time, whereby both the producer and consumer of the songs engage with the landscape in ways that are reflected in the music and in our memory'. Thus, the image of cities conveyed through song is fixed and static in the imagination, with particular sites, locations and neighbourhoods identified, mapped, trailed and toured by the musically minded tourist, with Penny Lane in Liverpool and Waterloo Bridge in London (evoking for fans of the Kinks the song "Waterloo Sunset") being prominent examples of locations frozen in musical time and imagination. Such associations with music and musicians that are judged to be canonical and/or that continue to be commercially successful internationally are perhaps an 'easy sell' when it comes to tourism promotion and this, what might be termed 'music genius tourism', or the 'memorialisation of people and cultural movements' (Gibson and Connell, 2007: 165) has been the subject of research attention by tourism scholars, cultural geographers and ethno-musicologists (Bennett, 2000; Bennett and Peterson, 2004; Carney, 2003; Chambers, 1985; Cohen 1991; Connell and Gibson, 2003; Kong, 1995; Krims, 2007; Shepherd, Laing and Horn, 2005; Roberts, 2012). 
Less well researched are provincial cities which can claim (and are keen to promote) their musical contributions but that do not possess the global, 'iconic' tourist appeal of Beethoven, Elvis and the Beatles.

In the UK, cities such as Bristol, Manchester, Newcastle and, as discussed in this paper, Sheffield attract niche, fan tourist audiences who visit sites associated with musicians from these cities and also to participate in live music 'scenes' (Cohen, 1999; Johansson and Bell, 2009). Alongside this, some provincial cities, such as Sheffield have state of the art recording and production studio facilities which attract major international artists, some of whom express views on their experiences of the city which may achieve the status of celebrity 'place endorsements'.

Cities are also birthplace and home to contemporary musicians who achieve critical and/or commercial success and who may express their views and sentiments about the place through song lyrics, album titles, CD liner notes, broadcasts, and interviews. City marketing agencies are understandably keen to be associated with artists who enjoy critical acclaim and international recognition for their work. To this end, such agencies may deploy images and sounds of these artists as part of 'boosterist' campaigns aimed at attracting business investment, tourism and media profile for their cities and to distinguish them as being in possession of a 'cool' genius locus when set against 'competitor' cities.

However, the urban 'soundscapes' produced by some musicians past and present transmit scenes and senses of decay, dereliction, drugs and despair that would not typically form part of the discourses of city marketing, while themes of fantasy, nostalgia and irony may also contribute to a 'sonic profile' and sense of place. Such musical associations may carry implications for some visitors' expectations; experiences and the places that they visit that may be at odds with 'official' city marketing imagery and the city centre locations that are typically promoted as places to visit (Cohen, Schofield and Lashua, 2010: 106). These observations represent a challenge to 'dominant mappings' of urban cultural spaces by tourism agencies and highlight the production of alternative narratives of the city through for example the work of artists mimicking the tropes of tourism mapping, text and promotion (Massey 2005; Roberts, 2012). In this regard, the emergence of particular styles of music in particular urban contexts, and the song lyrics, liner notes, and public statements of musicians may contribute subtly but significantly in shaping perceptions of place that are beyond the control of city tourism marketing agencies (Connell and Gibson, 2004: 3).

\section{Psychogeographical and city marketing perspectives on music tourism}

This paper adopts a 'psychogeographic' perspective in analysing 'lyrical places' (Gibson and Connell, 2007) and the locations 'mapped' by popular musicians and artists past and present, with a focus on the case of Sheffield, England. 
Psychogeography was conceived in Paris in the 1950s and in the Boston area of the USA in the 1950s and 1960s, in the disparate practices of the 'Situationist' radical art movement and of urban planners and geographers respectively. While Guy Debord was conceiving psychogeography as an activist / artistic project in Paris, planning Professor Kevin Lynch in Boston was laying the groundwork for what in the late 1960s became psychogeography interpreted as a humane approach to understanding, mapping and improving city planning, the professional practice of planners and critically, the lived experience of residents and, by implication, visitors (Debord, 2009; Lynch, 1960; McIntyre, 2012). Though varying considerably in style and rigour, both Debordian and Lynchian approaches were equally committed to the development of the relationship of the urban environment and the psychic, daily lives of individuals. Both depended heavily on walking as a practice and method, and both produced maps that have been influential on artists and some tourist guides and literature (Wood, 2010: 185).

Psychogeography in literature and what arguably may be considered to be travel writing has been popularised to an extent in the UK in recent years, most notably in the work of Iain Sinclair, writing and film-making mainly on aspects of London, including the city's marginal areas (Sinclair, 2002; 2009; Kotting and Sinclair 2012) and by the novelist, critic and cultural commentator, Will Self (Self and Steadman, 2007; 2009). The concept has also been applied explicitly by musicians and artists discussed in this paper as well as in playful forms of tourism and urban exploration that are presented as 'alternative' tourist practice in for example, the Lonely Planet Guide to Experimental Travel (Antony and Henry, 2005). Other recent publications that combine a critical, theoretical style with a guide for the curious resident and traveller include works by Coverley, with attention to Paris and London (2006) and Solnit, focusing on the USA (2006).

Psychogeography is thus a hybrid of academic theoretical framework(s), artistic practice, lifestyle statement and tourist guide. Mobility, principally through walking, is central and thus connects with travel and tourism, for example where, 'psychogeography direct[s] us to obscure places, to elusive ambient effects and partial artistic and literary precedents for the sublime.... Psychogeography was a reverie, a state of mind... It represented a drift from the ideal and the rational to the extraordinary and revolutionary' (Sadler, 1998: 76). Psychogeography as theory and practice is therefore a way of framing, mapping and traversing the complex identities of city environments including soundscapes and also suggests ways in which visitors may be directed to those 'obscure places' featured in song lyrics or implied in sound that may otherwise be overlooked in 'official' city marketing and maps, routes and trails.

Alongside this artistic and methodological project and more prosaically, there is growing research, practitioner and policy interest in the potential and actual contribution of popular music genres and musicians in shaping and conveying the identity of cities to tourists, businesses, residents and other audiences.

Typically this is expressed through 'creative industry', cultural and tourism development strategies (Brown, O’Connor, and Cohen, 2000; Cohen, 2007; Comunian, Chapain, and 
Clifton, 2010; Evans, 2009; Gibson and Connell, 2007; Kay, 2006; Long and Morpeth, 2012). A music tourism dimension to such strategies may include combinations of elements based on local histories and resources including; the promotion of sites of musicians' birth and death, places of historic and contemporary music production, support and encouragement of street performance 'buskers', urban music festivals, and museums (Connell and Gibson, 2004). Each of these mechanisms may be illustrated and problematised in the contexts of any city with a musical tale to tell as, in this paper, the case of Sheffield.

Mallinder (2011:110) suggests that these marketing efforts and music sector support programmes in northern English cities, and Sheffield in particular, can be traced to the period of de-industrialisation and resulting mass unemployment of the late 1970s / early 1980s where, '...urban economies in the past twenty five years have appropriated music to varying degrees to revitalize and re-image the contemporary city through the night-time economies and cultural industries'. This of course is not a static picture, and the extent to which urban and musical heritage and change is reflected in city marketing, place promotion, 'creative industries' and tourism agenda is variable (Cohen, Schofield and Lashua, 2010: 105). As Gibson and Connell (2007: 167) put it, 'music tourism constitutes evolving [emphasis added] clusters of tourists, activities, locations, attractions, workers and events that utilize musical resources for tourist purposes.' The relationships between a city's past contributions to popular music and emerging and changing contemporary music scenes are therefore important in seeking to understand and communicate a city's musical identity. Arguably, past popular music scenes and sounds have received more research and practitioner attention in relation to tourism than those of the present.

The conceptualisation and commoditisation of popular culture and musical creativity as 'industries' packaged for tourist consumption is problematic. At least some popular music and musicians present oppositional and antagonistic stances towards officialdom ('the man') and there is therefore a risk of a backlash from musicians (and their fans) who may object to being effectively 'state sanctioned' when tourism marketing managers assume their consent in being used, perhaps at times crassly and without permission, as an element of place promotion. Some of the tourism marketing literature, for example proposes the appropriation of musical genres and musicians without considering this fundamental, ethical consideration (Henke, 2005; Pearce, Morrison and Moscardo, 2003). Tensions may therefore exist between artistic, aesthetic, 'authentic' musical sensibilities, fan cultures and commoditisation.

Tensions may also be anticipated in local politics where governance, policing and city centre management may confront youth cultures, urban inequalities, race, class, drug and alcohol consumption and liminal behaviours associated with and expressed through popular music audiences in the 'night-time economy' (Hobbs, Lister, Hadfield, Winlow and Hall, 2000). We have moved on from the 1970s when some northern English cities were attempting to ban, or at least regulate punk rock performances, but It is perhaps unsurprising that there seems to be 
a tendency for cities to celebrate and promote a 'safer' music heritage aimed at attracting relatively prosperous and international tourists, rather than more 'edgy' scenes that may defy packaging.

\section{Methodology: approach, positionality, taste and emotion}

This research draws on a range of sources and informants. My approach involved a combination of face to face, phone and email interviews conducted between April - June 2012 with 19 people involved in the local (though nationally and internationally connected) music scene, with contacts extended through recommendations and networks. The individuals interviewed were: music promoters and venue proprietors, musicians, producers and recording studio owners, festival organisers, City Council marketing and city centre management officers and also Council 'Cabinet' members with portfolios for business, economy, jobs and culture, music journalists, an independent record shop owner, the landlord of a pub frequented by musicians and, the director of a fan club who is based in the city. Interview themes included; the nature of Sheffield's live music 'scenes', the ways in which Sheffield as a place has influenced musicians' work, how touring and recording musicians experience Sheffield in contrast with elsewhere and, comments on the city's venues and festival programme. Views on Council support for music and comments on live music and musicians being 'packaged' as tourist product were also solicited. All of the interviewees consented to be identifiable. Interviews were also sought with prominent Sheffield musicians Jarvis Cocker and Richard Hawley. Unfortunately, the timing of my approach conflicted with their touring and rehearsal schedules and they were therefore unavailable. Interviews were also not forthcoming with a representative of Sheffield International Venues, which operates the Arena and City Hall and also managers and proprietors of the Corporation, Plug and Leadmill venues.

I have also visited performance venues in Sheffield over the past 17 years and reflect on observations and informal conversations conducted during this period, although only in the period April - June 2012 were these noted as data. Recording studios, local media archives and the local studies section of the City Library which houses a small but well catalogued collection of resources relating to music were visited. Media sources included the documentary films 'Made in Sheffield' and 'The Beat is the Law'.

Interviews, observations and informal conversations were guided by the themes set out above but in some cases 'flowed' into discursive and relatively unstructured discussions of shared or contrasting knowledge, tastes and experiences in music.

Here it is necessary to acknowledge my positionality, tastes and emotions in relation to the subject of this research. As Lau and Pasquini (2006: 554) put it, 'positionality involves taking into account the factors which contribute to the shaping of a person's identity, worldviews and angles of perception....Positionality does not seek a deterministic reduction of a person's identity or work towards the sum of these influencing factors. Rather, positionality involves acknowledging these powerful influences so that they can be taken into account during the process of research'. In this regard, I recognise that my position as a 58 year old white, 
middle class male with particular musical preferences and knowledge could either establish my credentials or ignorance in relation to particular genres or scenes. My experience was that the people that I approached to participate in the research were, without exception friendly, interested and forthcoming. There was a genuine enthusiasm to talk with a warmth and humour characteristic of Sheffield, though not without some critical observations.

Also reflecting my positionality, I acknowledge that this paper is something of an homage to Sheffield and its music scenes. I lived in the city from 1995-2012, and regularly attended live music performances reflecting my eclectic personal interests in and some knowledge of Pub Rock, Folk, Americana, and Blues, Jazz, and Classical genres. These tastes were and are well served in the city. I acknowledge a tendency to romanticise Sheffield. To some extent, I attribute this to having enjoyed the vibrant music scenes that the city has to offer. However, I recognise that Sheffield, like other post-industrial Northern English cities, is a place with social problems and sharp class divisions between, in this case, its prosperous western and southern districts compared with the relative deprivation of the East and North (SFP, 2012). Like many middle class inhabitants of Sheffield, I seldom visited those parts of the city, areas where some musicians who have achieved popular and critical success since the 1970s-1980s came from and where some music scenes, such as ethnic, 'world' music persist.

\section{The Case of Sheffield}

Sheffield, with a population of around 555,000 (2010 census) is the fourth-largest city in England, located in South Yorkshire and close to the Peak District National Park, a part of which is situated within the city's boundaries. The hilly nature of the city, its river valleys, extensive green spaces and viewpoints provide a distinctive topography. Noted for high quality cutlery, silverware and pioneering steel production technologies, Sheffield's industrial base comprised a complex mix of large-scale steelworks, and small craft-based firms (the socalled 'little mesters') reliant on specialised metal trades, skills and markets. From the mid1970s, a combination of technological, market and political factors led to closures in the metal and mining sectors and mass redundancies within the city's workforce, with almost $75 \%$ of all jobs in these industries being lost by 1991 (Shepherd, Laing, and Horn 2005: 373).

This paper covers popular music in and from Sheffield and its emerging connections with tourism from the late 1970s to the present day, though antecedents in, for example rock and roll at Working Men's Clubs in the city from the 1960s and the dance halls of an earlier era are recognised as providing some historical context to more recent scenes. A large part of the story of popular music in Sheffield since the late 1970s relates to the responses of musicians to de-industrialisation, dereliction, redundant buildings and, unemployment (Anderson, 2010; Lilliker, 2005). Documentary films such as 'Made in Sheffield' and 'The Beat is the Law' and books such as Martin Lilleker's Beats working for a living: Sheffield popular music 19731984 tell the tale of musicians and proto-music sector entrepreneurs occupying former industrial premises, both officially and unofficially, and signing on the dole in order to pursue a life in music, whether commercially successful, enduring or otherwise. Post-punk bands 
such as Human League, Heaven 17 and, ABC did achieve commercial success and, indeed continue to tour (Bennett, 2007; Reynolds, 2005). Pioneering electronic band Cabaret Voltaire, while less successful commercially, were acknowledged by critics and other musicians as having been influential. Founding Cabaret Voltaire member Stephen Mallinder was interviewed for this research, and his recently awarded $\mathrm{PhD}$ (Mallinder, 2011) was valuable in its theoretical and participant perspectives on the emergence of Sheffield as a distinctive 'music city' with international connections.

As part of an 'official' response to the de-industrialisation of the late 1970s, a range of policy initiatives that sought to foster and promote music as a 'sector' within the nascent 'creative and cultural' industries and to a limited extent with tourism, emerged from Sheffield City Council. Council support for the establishment of the Red Tape recording studios, the Leadmill performance venue and the designation of the Cultural Industries Quarter (CIQ) were heralded as pioneering, albeit controversial developments more or less welcome among the members of a distinctly 'Old Labour' 'Socialist Republic of South Yorkshire' for whom music as an economic 'sector' lacking trade union membership may have been questionable (Brown, O'Connor and Cohen, 2000; Moss 2002). Moreover, the debacle surrounding the opening in 1999 and rapid closure in 2000 of the National Lottery funded 'Millennium Project' the National Centre for Popular Music (NCPM) may have added to a sense that music is high risk politically and that the Council should instead concentrate resources on its status as 'City of Sport' (although this was also politically contentious) (Mallinder, 2011; Moss, 2002).

However, the characteristics of the city's economy presented some difficulties that, '... required the implementation of strategies, which addressed issues of high unemployment and economic implosion.... The absence of a dynamic commercial or entrepreneurial sector necessitated a visible and pro-active role from the municipal sector and considerable public funding. Such approaches fed into planned strategies and specific zoning rather than the organic, laissez faire procedures, built on existing areas and economies, which characterized Manchester's later regeneration' (Mallinder, 2011, 110).

These comments highlight the need to reflect on the local specificity of place history, economy and cultures in devising local music (and tourism) plans and strategies, while recognising the relevance of comparisons and contrasts with other places.

Sheffield has a strong contemporary music scene and legacy including the recent international commercial and critical success of Arctic Monkeys, Richard Hawley, Jarvis Cocker and Pulp, which re-formed and toured internationally in 2012. Cocker also presents a critically acclaimed digital radio programme, the 'Sunday Service', to a national and international audience on BBC 6 Music, as part of which he presented a personal and evocative 'Musical Map' of his home city with strong psychogeographical overtones (Cocker, 2007).

In recent years the city marketing agency 'Creative Sheffield' (now Marketing Sheffield) has developed a programme focused on the city's contemporary music life and legacy from the 
1970s- '80s. Projects have included its sponsorship of a 'Made in Sheffield' CD with Sheffield born singer Tony Christie performing versions of material composed by Sheffield artists and also the promotion and sponsorship of an event programme that includes the 'Tramlines' free music festival with venues across the city centre featuring prominent local and national artists. There are also thriving and diverse local music scenes with some promoters, producers, venues and recording studios in the city enjoying a national and international reputation (Creative Sheffield, 2011).

\section{Research findings and discussion}

The analysis that follows is based on the themes, sources and informants identified previously. First, there is a discussion of music venues and associated 'scenes' defined by Cohen (1999) as involving communities brought together by shared, though at times nuanced and intersecting tastes, fashions, styles, and notions of authenticity in various genres of popular music.

The aural, psychogeographical soundscapes of Sheffield, as reflected in the compositions and published outputs and interviews with musicians and artists, forms the next section. These findings were not anticipated when embarking on the research, but emerged as a strong theme. Attention then turns to the views of musicians, producers, promoters and others involved in the music 'sector' on the place of popular music in the cultural and tourism policies and strategies in Sheffield. Their comments are set alongside those of City Council officers and local politicians with interests and portfolios in these policy spheres. A final section concerns fan cultures and the views of visiting musicians on their experiences of the city.

\section{Contemporary music venues and associated music 'scenes'}

The scenes considered here reflect my personal tastes and familiarity with particular genres and venues. Variants of 'metal', though not addressed in this research, are represented in Sheffield and the city made contributions in this genre (Anderson, 2010). For example, fans of Def Leppard may obtain a sheet from the City Library that maps sites in Sheffield associated with this band. Interestingly, this material was not available on enquiry at the City Tourist Information Centre (TIC), nor was there much else there that may be of interest to a 'music tourist'. Currently, metal scenes exist, and I understand are well attended at the Corporation club in the city. Unfortunately perhaps, this is a scene that passes me by.

Music scenes that align with my tastes include contemporary and 'traditional' folk, 'pub rock' and Americana. These genres are very well served in Sheffield and in particular at the 'Greystones' public house in a suburb of the city. This premises was taken over and refurbished by an award winning real ale brewery (Thornbridge) in 2010. The pub's relaunch emphasised live music and included the opening of its 200 capacity 'Music Room' on the site of the Highcliffe folk club which had been popular there in the 1960s-70s. The folk 
music strand remains prominent in the Greystones programming and in Sheffield more widely, with roots and connections traceable to rural English folk traditions such as the Grenoside Sword dancers (who have toured internationally) and in nearby Peak District villages. Another dimension to the strength of the folk scene is the urban socialist, industrial working class folk protest genre, represented for example by Roy Bailey, who has performed regularly with 'old' Labour politician Tony Benn.

Sheffield is also home to some highly acclaimed contemporary folk musicians including Martin Simpson, Fay Hield and Jon Boden and also Kate Rusby from nearby Barnsley. A programme of performances by such artists and other musicians who are rated highly in the scene nationally is organised, under the Bright Phoebus label by Martin Simpson's partner and interviewee Kit Bailey (who is involved with the scene nationally through her work on the BBC Radio 2 Folk Awards and is Roy Bailey's daughter).

During our interview, Kit highlighted the enduring nature of the folk scene in Sheffield, attributable in part to the many folk performers living in the city and also with regular visiting musicians. She also suggested that Sheffield's central location is convenient for touring artists. The left-wing working class and also middle class intellectual traditions of the city which included folk music involvement with the miners' strike and the 'Folk against Fascism' movement were also noted by Kit as characteristic of the city.

Related to folk and also prominent in the programming at the Greystones are variations of 'new wave' Americana music with folk, bluegrass and 'Alt Country' styles featuring young, critically acclaimed musicians from the USA and Canada touring small - medium scale venues in Europe such as the Greystones.

Chris Wilson, the promoter of these acts, told me that he has developed strong connections with these emerging scenes and that he travels to North America regularly to sign up artists. Chris also has close and long established links as a promoter with 'pub rock' artists, such as Dr Feelgood, who perform regularly in Sheffield, as band leader Wilko Johnson 'is fond of the city'. He also reported a good relationship with performers who attract dedicated fan followings such as John Otway, John Cooper Clarke and, Half Man Half Biscuit. I have observed and spoken with audience members before, during and after performances of these and other comparable artists over several years and they do indeed attract visitors from outside of Sheffield to their performances.

Chris Wilson had also been the leading promoter at the Boardwalk venue from 1996 up to its closure in 2011. This venue is much missed by local music fans and was mentioned by several informants as having been the closest thing that Sheffield had to an 'iconic' venue, comparable with Eric's in Liverpool and, arguably with the Hacienda in Manchester. The 400 capacity Boardwalk's closure was due to a complex dispute over its lease and was unremarked in the local media as they did not feel that they were in a position to cover the story in view of legal issues (Rachael Clegg, Sheffield Telegraph, personal communication). Chris Wilson was outspoken during our interview about what he saw to be a lack of City Council support for the Boardwalk. In his view a lack of interest from the Council and arts 
agencies was due to the venue being in the 'wrong end of town', located as it was in the unfashionable Markets district on the fringe of the city centre. His argument was that the city centre (re-branded 'Heart of the City') and the Cultural Industries Quarter (CIQ) continue to be the favoured areas and beneficiaries of regeneration initiatives, with the Boardwalk and its environs neglected. According to Wilson the Boardwalk did attract small numbers of international music tourists who would visit the site due to its connections with for example, Joe Cocker who first performed there in the 1960s. The venue was also host to early gigs by the Sex Pistols and the Clash, and Chris had observed foreign tourists photographing themselves outside the building because of these associations.

\section{The aural, psychogeographical soundscapes of Sheffield}

'Listening to the city' was a theme developed by several research informants who commented on a particular and distinctive aural quality that was influential on some musicians working in Sheffield during the late 1970s and early 1980s. Mallinder observes that, 'the 'sound' of the city is framed by its industrial corporeality, its elemental essence contained in rolling mills and blast furnaces' (2011: 88). Other interviewees and sources shared this view that the industrial noise of the city and its post-industrial landscape were influential on musicians working in the city at that time.

Mallinder notes the dynamic, complex and enduring nature of this soundscape and its expression through music, '[Sheffield] has redefined itself aurally, characterized, through a bricolage of archaic industry and shiny technology, the city's rhythms have reverberated through popular music forms. A paradoxical fusion - the sounds of metal and soul, steel and electronica, industrial bleeps and lyrical mockery - popular culture wrapped in the tarnished glamour of self depreciation: the noise of iron and irony' (2011: 84).

An ironic self-deprecating humour, reflecting a wider local cultural characteristic, is very much a feature of the recent and contemporary Sheffield sound. This is exemplified by the lyrics, interviews, reviews and broadcasts of Jarvis Cocker, Alex Turner of the Arctic Monkeys and, Richard Hawley. An ironic and even mystical, undercurrent is discernible in work that draws attention to suburban and working class neighbourhoods such as; Intake, Manor Park, Catcliffe and Attercliffe as Jarvis Cocker does on Sheffield: Sex City. While Richard Hawley features Cole's Corner, Lowedges, Truelove's Gutter, Lady's Bridge, and Skye Edge as album titles, all referring to locations on the margins of the city. There is no reference here to the 'heart of the city' or the various 'quarters' which are the focus of the Council's tourism marketing. In a recent interview to coincide with the release of his latest album, Standing at the Sky's Edge, Hawley notes that, "it's a nod to the city for nourishing me and giving me inspiration and it's a mark of respect. It's Richard Hawley's psychogeography of the city, if you like. I've got a long-term game plan - I'm trying to boost tourist trade in Sheffield." (Interview with Rachael Clegg, Sheffield Telegraph 3/5/12). Hawley's love for the city is well known and frequently declared. He may regularly be found 
at the pub Fagan's (featured photographically by Martin Parr on the 'Truelove's Gutter' album cover), where Tom the landlord confirmed to me that he quite often has tourists come in who are following self-directed Hawley trails.

A feeling for Sheffield and frequent references to the city are also expressed In Jarvis Cocker's edited collection of lyrics. He notes, 'It wasn't until I moved away from Sheffield in 1988 that I began to write explicitly about the place.....Then I wrote about it in a frantic attempt to stop it fading from my memory......you can mess with the order and adjust the lighting when needs be. You're the boss after all - it's your kingdom' (Cocker, 2011: 4).

The work of a group of environmental activists / artists who style themselves as a 'dream tourist agency for the city' reveal an aural and visual mosaic that mythologizes and maps locations, routes and trails in Sheffield. In calling themselves the Sheffield Publicity Department (SPD), they have adopted the logo of the City Council's 1970s proto-tourist office in producing work that effectively operates as an alternative tourist information service with a narrative style that may be contrasted with the language of more 'official' guides. In 2012 and as part of the Sensoria Music Film Festival, SPD produced an idiosyncratic, limited edition 'Sheffield Music City' tourist guide to locations associated with local music scenes past and present. An example of their rather romantic, ironic style comes from the text of a leaflet produced for the city's 'Tramlines' music festival in 2011:

"If this is your first visit, let us say this: don't panic. Yes, it may appear that the city is just a random collection of scruffy modern buildings, competing bus companies and one-way streets, with no attempt made to join them together. And yes, the uninitiated may be shocked by the sheer amount of wasteland, as if Sheffield has only recently lost a war. But rest assured this is not the full picture. There's a way to see our city in a different light. It's just about knowing where to see it from. Let us take you to a viewpoint. It's only five minutes away. We'll start at the train station. Go inside, up over the bridge towards the trains, and out the door at the end. Keep going, up those rusty steel steps in front of you, all the way to the top. And then turn around. Here, below you, is our city. From here, the city centre is a pop-up history book, where '60s office blocks rub up against mock-Tudor Victorian pubs, and 1980s science parks. And from here, the empty spaces are like breathing space for the city, where the weeds blossom every spring like a post-industrial flower show. And somewhere in this mess are the musicians and artists and designers, working now, even now, to put the name of this city on the lips of the world. And above the city you can see our hills, covered with terraced houses, like the crowds at a football match. And from here you can see our trees, bursting out of the roads, covering the suburbs with green. And further away, at the edge of the frame, you can see the bare brown lines of the Peak District, the space where the city spends its weekends....."

Attention is now turned from the poetic and psychogeographic representations of Sheffield through art and music to more pragmatic and policy oriented perspectives on music and tourism in the city.

\section{Sheffield 'Music City'?}


This section draws on interviews, policy and strategy documents on the promotion of Sheffield as a 'music city' and the harnessing of this identity for the purpose of attracting tourists. The first interview discussed here was conducted with Martyn Ware, a founding member of the post-punk electronic pop bands, Human League and Heaven 17, both of which achieved chart success in the 1970s-1980s and continue to periodically re-form and tour (Reynolds, 2012; 2005). The second interviewee, Stephen Mallinder, was a founding member of influential electronica group Cabaret Voltaire. Both interviewees remain prominent in the international music industry while continuing to visit and promote Sheffield's music scene in various ways. Interestingly, both also have academic dimensions to their work.

Martyn Ware confirmed that he visits Sheffield very regularly, as he has family in the city. He supports in broad terms the work of Sheffield City Council in seeking to encourage the music sector, and he would be interested in contributing to a 'steering group' to examine what more could be done in support of music in the city. In his view the city 'does not make enough of its substantial contribution to popular music and record of innovation and experimentation.' There is a sense at the Council of "let's not go there" after the failure of the NCPM.

Martyn noted that he has recorded the sounds of factories and workshops and that such industrial sounds of Sheffield contributed to the inspiration of electronica and his more recent work in '3D Soundscapes'. He noted that this innovation continues in the work of Bill Drummond at the Forgemasters factory as part of the Sensoria programme. From his experience, people in the international music industry have 'nothing but fondness' for Sheffield and appreciation for the city's contributions. He contrasted this with 'Manchester [which in his view] is full of hubris.'

Stephen Mallinder completed his $\mathrm{PhD}$ on music and popular culture in Australia in 2011 and has since held an academic position in Media Studies. His recent research and development work has included projects for the UK Department of Culture, Media and Sport on university 'engagement' with the creative and cultural Industries. Steve's $\mathrm{PhD}$ is particularly relevant to this research as he presents a theoretically rich analysis of the Sheffield soundscape drawing also on his prominent personal contribution. He discusses some interesting comparisons between Sheffield and the soundscapes of Detroit and Dusseldorf, which share some characteristics and antecedents. Our interview discussion followed similar lines to that with Martyn Ware. Steve Mallinder also retains close links with Sheffield and visits the city regularly. He has participated in both the Tramlines and Sensoria festivals and is also broadly complimentary about the City Council's efforts in support of contemporary music and musicians, though he felt that contemporary dance and techno scenes in Sheffield are under appreciated.

The next two interviewees are prominent Sheffield producers and musicians who run recording studios in the city with international reputations and impressive records of attracting major artists to record in the city. 
The first of these was a telephone interview with Eliot Kennedy, Director of the Steelworks Studios, where he has produced and played bass guitar with artists including Gary Barlow (with whom he composes and also performed at the Queen's Diamond Jubilee celebrations), Celine Dion, Bryan Adams and the Spice Girls, all of whom have worked in Sheffield and, according to Eliot, enjoyed their experiences of the city. Eliot suggested that artists have a productive time in Sheffield as it is possible to have a 'good working day' without the distractions of public and media attention to which they are prone when working in major cities. For Eliot, 'it's easy to function [as a producer and musician] in Sheffield' and the city possesses, 'affordable world-class facilities' in former industrial buildings that are very well suited to adaptation as studio spaces close to the city centre, with London accessible in 2 hours by train. 'Geography is therefore not an issue.' Eliot noted that his international visitors are always impressed on arrival, with the example given of the recent visit by a Director of Decca Records.

He was also very complimentary about the work of the 'user friendly' Council and that Steelworks Studios location in the CIQ helps, along with, importantly a strong local 'community of musicians' with the electronic, post-punk scenes being very strong, along with the ironic sense of humour epitomised by the Arctic Monkeys and Jarvis Cocker that is characteristic of Sheffield. In comparison with other cities for Eliot, Manchester is 'much angrier' and Liverpool 'can't get away from the Beatles', while 'Sheffield being under the radar adds cool'. This feeling that 'nobody's watching us' compared with 'the surveillance of London and other major cities' is conducive to composition and production processes. In support of Mallinder's views, Eliot also suggested that comparisons between Sheffield and Detroit make sense as both cities have shared experience of music being a central part of regeneration programmes after a period of industrial decline (Che, 2009).

The second producer / musician interviewed was Colin Elliot, bass player and producer with Richard Hawley's band and Director of Yellow Arch Studios. Colin has also worked with among others Kylie Minogue, Jarvis Cocker and Duane Eddy. The interview took place at the Studios which are located in a nondescript former nut and bolt factory, with no external signage. Internally, the building includes a state-of-the art recording studio and rehearsal rooms. Posters featuring albums recorded there line the walls. It is comfortably furnished with a lived in feel. Colin observed that the existence of such spaces lend themselves well for recording and rehearsal, are comparatively cheap, and an advantage of the city. Yellow Arch Studios was set up 15 years ago by Colin with his business partner and drummer Andy Cook. It is a success and is well used. As he put it, "things happen easily in Sheffield", there is a good 'pool' of musicians that can be called on locally, with particular strengths in electronica and guitar bands. Classical and jazz musicians are though comparatively lacking in the city.

Along similar lines to others, Colin suggested that there is a 'Sheffield mentality' exemplified by Arctic Monkeys and Jarvis Cocker that is 'wry, grounded, ironic, doesn't take itself too seriously and is based on everyday observation and humour.' He contrasted this favourably with music styles associated with Manchester and Liverpool. He commented that he has no 
real interest in the work of the Council in connection with culture and tourism though thought that 'they do some good things' such as support for the Tramlines festival, with Yellow Arch having featured as a venue in 2012. He had mixed views on the legacy of Red Tape Studios and Council sponsored training programmes as these had not fed through to Yellow Arch, though the principle of encouraging young people into music is good. In Colin's view, 'Sheffield lacks iconic and good venues', noting the loss of the Boardwalk, with the Greystones excellent but small. From Colin's professional perspective, the O2 Academy is acoustically poor and the Leadmill is uncomfortable.

City Council views on popular music and tourism were obtained from the Director of the Marketing Sheffield agency, Brendan Moffett; City Centre Manager, Richard Eyre and; Council Cabinet members with responsibilities for business and culture (at the time of the interviews). Reference was also made to recent and current tourism, culture and economic strategy and policy documents (Creative Sheffield 2011; SFP, 2012).

Brendan observed that he has excellent personal and professional contacts with the Sheffield music sector. It was clear during our interview that he has personal tastes and knowledge of the local music scene that may distinguish him from some of his predecessors, who, on the basis of my past encounters with them, appeared to lack such awareness. He recognised that the relationship between city marketing and tourism people 'with the talent' can be problematic and acknowledged Richard Hawley's robust views on the City of Culture proposal, recognising that the Council and tourism are 'not very rock and roll'! Accordingly, Brendan works mainly through managers and promoters and recognises the need to be 'hands-off and not prescriptive'. He confirmed that the Council is 'interested in live music promotion and a festival programme as an economic driver' and that these have had some success in attracting national and international media attention and some private sector sponsorship. Brendan argues that the city is keen to 'use its assets including buildings and venues but also the street, squares and public realm' most conspicuously during the Tramlines festival. He is also keen to promote an 'industry interface' through the Sensoria music and film festival. Brendan recognises the case that there is a 'venue gap' in the city and noted concern about competition from the new Leeds Arena, which has attracted controversy over its being publicly funded in contrast with Sheffield Arena with which it will compete.

The interview with City Centre Manager Richard Eyre focused mainly on the Tramlines festival, where extensive use is made of the public realm. Richard explained the classification of ' $\mathrm{S}$ ' brand events, which are those events sponsored by the Council and which are required to make use of official City branding (the 'Sheffield' typeface for example). These contrast with events which are deemed to be 'City' ("For Sheffield, by Sheffield"); 'community' (neighbourhood, parks, street parties, ethnic); and 'civic' (official ceremonial involving for example the Master Cutler and Lord Mayor). Richard confirmed that Tramlines is now classified as 'major' with the aim of attracting more visitor spending, which he also 
recognised is harder to demonstrate than sport events, though he claimed that evidence does exist of economic benefit for pubs, clubs and restaurants that would otherwise struggle during University vacations and the absence of the 55,000 student population. Richard also argued that 'the Council will never drive the music sector' but that it does wish to perform a 'facilitating, enabling role' through the emerging Sheffield Music City programme. There is recognition that the city's music legacy and current activity is a 'hidden gem'.

Both Brendan and Richard as Council officers argued that there is broad political support for music and tourism initiatives in the city though funding is tight in view of cuts imposed on local government. The interviews with Councillors who held City Cabinet leads roles for Business, Jobs, Skills and Development supported this view, noting that, "we have and continue to work closely with a number of local promoters to develop ways of improving marketing (i.e., fly-posting zones, sites, permits etc). We also actively encourage busking across the city centre via our permit scheme. The councillors also emphasised support for music education programmes for children and young people, where 'Sheffield has a number of informal and formal music-making opportunities available for young people in and out of schools. Some of these have been supported by the Council either through funding or other forms of support.'

As regards tourism, the councillors claim that, 'Sheffield is essentially trying to help raise the profile of the live music scene in Sheffield. This involves sponsorship/commissioning of Tramlines, and of Sensoria and other festivals and events which fit the brand and build tourism for the city. There is clearly a role for reflecting the music scene as part of the 'authentic and independent' Sheffield city brand which is part of a wider approach to marketing the city to external audiences and raising the city's profile generally.' However, in response to a question concerning comparisons with other cities, 'we don't do any benchmarking in relation to music in terms of city competitiveness. We have tried to do some benchmarking in relation to tourism but the issue tends to be with the availability of useful and comparable data.'

\section{Fan cultures and music tourism}

An unanticipated finding in this paper concerns fans travelling to Sheffield for the main purpose of consuming both recorded and live music. The first observation relates to independent record shops (i.e. that are not part of chain retail groups). The appeal but decline of such stores, in the face mainly of competition online has been covered recently in the documentary film and book 'Last Shop Standing' (Jones, 2012) and also by McIntyre in connection with the pleasures of browsing in such stores (2009). Record Collector in the Broomhill district of Sheffield is a good example of this kind of shop. It is well supported by local musicians, some of whom have performed at the shop and have released collectible recordings on vinyl that are available exclusively there. Visiting artists also regularly come to Record Collector in search of rare items and unanticipated discoveries. Joe, a worker in the area of the store devoted to vinyl records, noted that people did visit from distance to browse, giving an example of a recent customer from New York looking for John Mayall albums that 
are hard to find in the US. However, he also observed that they have no contact with the Council concerning promoting Record Collector as part of a music trail.

Record Collector does not have a website and the store owner has concluded that it would be impossible to catalogue their stock online. There also appears to be a cachet in not being accessible online, with a customer noting to me during a visit to the store that needing to browse in the hope of making a chance discovery is a distinct pleasure of this particular retail experience.

My second, contrasting and final reflection on fan cultures emerged in 2011 with the release of the album 'Road Trip' from rock and roll guitar legend Duane Eddy. This new album, Eddy's first in many years, was recorded and produced with Richard Hawley and band at Yellow Arch Studios, Sheffield. Their performance at the Greystones Music Room as a warm up for the Glastonbury Festival was extraordinary. This event received national BBC news coverage.

I subsequently discovered that the Duane Eddy Circle fan club has been run from Sheffield since 1983. I joined the Circle and interviewed its secretary, who told me that the club has 450 members, most of whom are male, of UK and European origin and aged over 50. A regular newsletter is published, and an annual convention is held in London. He noted that many Circle members travel to follow Duane on tour, though this is becoming constrained by age. I witnessed this at Duane Eddy's gig at the Leadmill, Sheffield on the $14^{\text {th }}$ May 2012, where I met a couple in their early 70s from Hamburg who were attending each concert on that UK tour and who, along with other Circle members, often meet Duane after his concerts. I contacted Duane Eddy to ask for his experiences of being in Sheffield and his thoughts on the city. His comments included that he loved being in the city for 3 weeks during the recording of 'Road Trip' singling out his appreciation of the local people that he encountered during visits to Indian restaurants and Fagan's pub.

Duane equated Sheffield with Phoenix in the 1950s and that he meant this as a compliment as it is a city 'lacking pretensions' and 'without ego'. He recalled playing Sheffield in the 1960s though spent little time in the city then as was and is typical among touring musicians. Since returning to record Road Trip with Richard Hawley, he has 'fallen in love' with the place and is seriously considering buying a property in the city. Another consequence of Duane Eddy having recorded in Sheffield has been growing interest expressed by US media in the city and its music scene and requests for interviews with Richard Hawley (Colin Elliott, personal communication).

\section{Conclusions}

This paper has presented a generally positive view of Sheffield as a music tourism city. Genuine affection for the city, its people and music scenes are observed here, albeit with this researcher's positionality in relation to its subject acknowledged. 
The City Council's 'light touch' supportive and encouraging stance towards the music sector was acknowledged by most informants and would stand comparison with other cities as a model of practice, strategy and policy. However, some potential tensions and critical issues are suggested here.

The first concerns tensions between artistic sensibilities and 'official' City discourses and the enlisting of musicians and artists as city marketing 'ambassadors'. In contrast to (most) sportspeople, enlisting musicians and related practitioners as part of economic regeneration and city marketing strategies is challenging. Mallinder puts this well noting 'the inherent problems of institutionalizing popular cultural forms and a resistance of sound to being anchored and contained' (2011:82).

Second, a tension (or paradox) exists between the understandable desire by city marketing agencies to engage in tourism promotion while claiming 'hidden gem', 'below the radar' status. Ultimately, this is a matter for skilful and targeted marketing that works with, or at least acknowledges that artistic interventions in tourism are at least acceptable and may be more effective than official campaigns but that they may not wish to be officially branded. 'Alternative' mappings of the city should be encouraged sensitively and without compromising their being 'alternative' (Lashua, Cohen and Schofield, 2010).

Next, there are tensions between the typical city marketing rhetoric of having to 'compete' as music tourism destinations against prospects for collaboration with cities with comparable and shared soundscapes. However, the issue of competition is real as observed by Cohen (2007: 127) when she participated in a delegation from Liverpool on an official visit to Sheffield in September 1988, where ...'upon our arrival in Sheffield we were met by the leader of Sheffield City Council, various council officers and members of the Human League.... We were taken to see the recording studio that the Human League had built in Sheffield's newly developed Cultural Industries Quarter (CIQ) and during a guided tour of that Quarter we were shown how an area that had recently housed a concentration of derelict industrial warehouses had been transformed into a conglomeration of subsidized facilities for local music and film businesses'. However, this openness was reflected on by Cohen in a footnote where she noted that, 'the meeting was not a great success, much to the dismay and irritation of its Sheffield-based organizer, who complained to us later that apart from the manager of Amazon Studios the Liverpool visitors appeared to be inexplicably unforthcoming about their own cultural projects and plans' (Op Cit.).

More positively, and as noted by Mallinder (2011), there are real and interesting recent historical sonic connections between Sheffield's contributions to electronica, with Detroit's Techno scene (see also Che, 2009) and Dusseldorf's 'Krautrock'.

These connections can be creatively fostered and developed through festival programmes such as during Sensoria 2012 where Clegg (2012) notes in a newspaper report, 'the premise of the Motor City vs. Steel City event is interesting - both cities were production powerhouses, Detroit being most famous as the home of Ford's motor plant, whose operating 
conveyor belts once spanned more than 90 miles. Sheffield, of course, is the home of steel production and as a result, in its former life, mass employment. But the demise of these industries led to the creation of inventive electronic music - in Sheffield acts...started to lay down ingenious electronic sounds, crafted from initiative and poor equipment. In Detroit techno replaced the Ford motor car and Motown music as the city's main export. Both Sheffield and Detroit are musically-motivated cities but there's a tension in the music too.'

Final observations and suggestions for further research both in Sheffield and other cities concern how local music scenes come about. What does it take for a local scene to take shape and how, or perhaps should these scenes be endorsed as tourist product? This article suggests that research attention might usefully be directed to the relative location and size of place and audiences; the networks of musicians and related practitioners; local socio-economic environments, atmosphere and social structures; strategies of urban development, city marketing, tourism and music infrastructure in the context of the creative industries and; the existence or otherwise of a supportive local media and national / international media coverage (Johansson and Bell, 2009: 220-225). 


\section{References}

Anderson, N., (2010) Signing on for the Devil: Sheffield-Metal Capital of the 1980s.

Sheffield: ACM Retro.

Antony, R. and Henry, J. (2005) The Lonely Planet Guide to Experimental Travel. Footscray: Australia.

Bennett, A. (2007) 'The forgotten decade: rethinking the popular music of the 1970s', Popular Music History 2 (1): 5-24.

Bennett, A. (2006) 'Punk's not dead: The continuing significance of Punk Rock for an older generation of fans', Sociology 40 (2): 219-235.

Bennett, A. (2000) Music, identity and place. London: Macmillan Press.

Bennett, A. and Peterson, R. A. (eds.) (2004) Music scenes: local, translocal, and virtual. Nashville: Vanderbilt University Press.

Bestley, R., 2012. 'From 'London's Burning' to 'Sten Guns in Sunderland', Punk and PostPunk, 1 (1): 41-71.

Brown, A., O'Connor, J. and Cohen, S. (2000) 'Local music politics within a global music industry: cultural quarters in Manchester and Sheffield', Geoforum 31: 437-451.

Carney, G. (2003) The Sounds of People and Places: A Geography of American Popular Music from Country to Classical and Blues to Bop. Lanham, MD: Rowman and Littlefield.

Chambers, I. (1985) Urban Rhythms: Pop Music and Popular Culture. London: Macmillan Press.

Che, D. (2009) Techno: Music and Entrepreneurship in Post-Fordist Detroit in Johansson, O. and Bell, T. (Eds.), Sound, Society and the Geography of Popular Music. Burlington, VT:

Ashgate.

Cherry, B. and Mellins, M. (2012) Negotiating the Punk in Steampunk: Subculture, Fashion and Performative Identity. Punk and Post-Punk, 1 (1): 5-25.

Clayton, I. (2009) Bringing it all back home. Pontefract: Route Books.

Clegg, R. (2012) It's forge versus Ford. (Sheffield Telegraph, $26^{\text {th }}$ April).

Cocker, J. (2011) Mother, Brother, Lover: Selected Lyrics. London: Faber and Faber.

Cocker, J. (2007) Music Map of Sheffield. [online] Available at:

<http://www.youtube.com/watch?v=qpqMxIthJY4> [Accessed 28 August 2012]

Cohen, S. (1999) Scenes. In, Key Terms in Popular Music and Culture. Horner, B. and Swiss, T. (Eds.), 239-249. Malden, MA: Blackwell. 
Cohen, S. (2007) Decline, Renewal and the City in Popular Music Culture: Beyond the Beatles. Aldershot: Ashgate.

Cohen, S. (1991) Rock Culture in Liverpool: Popular Music in the Making. Oxford University Press.

Cohen, S., Schofield, J. and Lashua, B. (2010) Music, characterisation and urban space. Popular Music History, 4(2): 105-110.

Comunian, R., Chapain, C., and Clifton, N. (2010) 'Location, location, location: Exploring the complex relationships between creative industries and place', Creative Industries Journal. 3 (1): 5-10.

Connell, J., and Gibson, C. (2004) 'Vicarious Journeys: Travels in Music', Tourism Geographies 6 (1): 1-24.

Connell, J., and Gibson, C. (2003) Sound tracks: Popular music, identity and place. London: Routledge.

Coverley, M. (2006) Psychogeography. London: Pocket Essentials.

Creative Sheffield (2011) A culture strategy for Sheffield 2011, 2012 and 2013. Sheffield City Council.

Debord, G. (2009) Society of the Spectacle Translated from French by K. Knabb. Eastbourne: Soul Bay Press.

Eddy, D. (2011) BBC Breakfast News interview. [online] Available at: <http://www.youtube.com/watch?v=mfzvY3oUc98> [Accessed 28 August 2012]

Evans, G. (2009) 'Creative cities, creative spaces and cultural policy', Urban Studies 46: 1003-1040.

Frost, W. (2006) 'Rock Music and Tourism: The making of ACDC Lane', Tourism, Culture and Communication 6:215-216.

Gibson, C., and Connell, J. (2007) 'Music, Tourism and the Transformation of Memphis', Tourism Geographies 9 (2): 160-190.

Henke, L. (2005) 'Music Induced Tourism: Strategic use of indigenous music as a tourist icon', Journal of Hospitality and Leisure Marketing 13 (2): 3-18.

Hobbs, D., Lister, S., Hadfield, P., Winlow, S., and Hall, S. (2000) 'Receiving shadows: governance and liminality in the night-time economy', British Journal of Sociology. 51 (4): 701-717.

Johansson, O. and Bell, T.L., (eds.) (2009) Sound, Society and the Geography of Popular Music, Burlington, VT: Ashgate 
Jones, G. (2012) Last Shop Standing: Whatever happened to record shops? London: Proper Music Publishing.

Kay, A. (2006) 'Promoting tourism through popular music', Tourism, Culture and Communication 6: 209-213.

Keeling, D. (2011) 'Iconic Landscapes: The Lyrical Links of Songs and Cities', American Geographical Society's Focus on Geography, Winter: 113-125.

Kong, L. (1995) 'Popular Music in Geographical Analysis', Progress in Human Geography, 19 (2): 183-198.

Kotting, A., and Sinclair, I. (2012) Swandown. [online] Available at:

$<$ http://www.imdb.com/company/co0377849/> [Accessed 28 August 2012]

Krims, A. P. (2007) Music and Urban Geography. New York: Routledge.

Lashua, B., Cohen, S. and Schofield, J. (2010) 'Popular music, mapping and the characterisation of Liverpool', Popular Music History 4(2): 126-144.

Lau, L. and Pasquini, M. (2006) “"Jack of all trades"? The negotiation of inter-disciplinarity within geography', Geoforum 39: 552-560.

Lilleker, M. (2005) Beats working for a living: Sheffield popular music 1973-1984. Sheffield: ACM Retro.

Long, P., and Collins, J. (2012) Mapping the Soundscapes of Popular Music Heritage in: Roberts, L. (Ed.) Mapping Cultures: Place, Practice, Performance. Basingstoke: Palgrave Macmillan.

Long, P.E., and Morpeth, N. (2012) Critiquing Creativity in Tourism, in Smith, M. and Richards, G. Routledge Handbook of Cultural Tourism. Abingdon: Routledge.

Lynch, K. (1960) The Image of the City. Boston, Mass: MIT Press.

Mallinder, S. (2011) Movement: Journey of the Beat. Unpublished PhD thesis, School of Media Communication and Culture, Murdoch University, Western Australia

Massey, D. (2005) For Space. London: Sage.

McIntyre, C. (ed.) (2012) Tourism and Retail: The psychogeography of liminal consumption. Abingdon: Routledge.

McIntyre, C. (2009) 'Diminishing varieties of active and creative retail experience: The end of the music shop?', Journal of Retailing and Consumer Services, 16: 466-476.

Moss, L. (2002) 'Sheffield's cultural industries quarter 20 years on: what can be learned from a pioneering example?', International Journal of Cultural Policy 8 (2): 211-219. 
O’Brien, L. (2012) 'Can I have a Taste of Your Ice Cream?' Punk and Post-Punk, 1 (1): 2740 .

Pearce, P., Morrison, A., and Moscardo, G. (2003) 'Individuals as tourist icons: A developmental and marketing analysis', Journal of Hospitality and Leisure Marketing, 10 (1/2): 63-85.

Prior, N. (2011) 'Critique and renewal in the Sociology of Music: Bourdieu and beyond', Cultural Sociology 5 (1): 121-138.

Reynolds, S. (2005) Rip it up and start again: Postpunk 1978-1984. London: Faber \& Faber.

Roberts, L. (ed.) (2012) Mapping Cultures: Place, Practice, Performance. Basingstoke:

Palgrave Macmillan.

Rose, G. (1997) 'Situating knowledge: positionality, reflexivities and other tactics', Progress in Human Geography 21 (3): 305-320.

Sadler, S. (1998) The Situationist City, Cambridge, MA: MIT Press.

Self, W. and Steadman, R. (2009) Psycho Too, London: Bloomsbury.

Self, W. and Steadman, R. (2007) Psychogeography, London: Bloomsbury.

Seman, M. (2010) 'How a music scene functioned as a tool for urban redevelopment: A case study of Omaha's Slowdown project', City, Culture and Society 1 (4): 207-215.

SFP. (2012) State of Sheffield 2012. Sheffield First Partnership.

SPD. (2012) Sheffield Music City. Sheffield Publicity Department and University of Sheffield.

Shepherd, J., Laing, D., and Horn, D. (eds.) (2005) Continuum Encyclopedia of Popular Music of the World: Part 2 Locations. London: Continuum.

Sinclair, I. (2009) Hackney that Rose Red Empire. London: Hamish Hamilton.

Sinclair, I. (2002) London Orbital. London: Granta.

Sneeringer, J. (2001) 'John Lennon, Autograph Hound: The Fan-Musician Community in Hamburg's Early Rock and Roll Scene, 1960-65', Transformative Works and Cultures, [online] Available at http://journal.transformativeworks.com/index.php/twc/article/view/228 [Accessed 15 January 2013]

Solnit, R. (2006) A Field Guide to Getting Lost. London: Canongate Books.

Whiteley, S., Bennett, A. and Hawkins, S. eds. (2004) Music, Space and Place: Popular Music and Cultural Identity. Aldershot: Ashgate. 
Wood, D. (2010) 'Lynch Debord: About Two Psychogeographies', Cartographica 45 (3): 185-200. 